\title{
ZADOVOLJSTVO STUDENATA LIBERTAS MEĐUNARODNOG SVEUČILIŠTA PROVEDBOM NASTAVE ZA VRIJEME PANDEMIJE BOLESTI COVID-19
}

\begin{abstract}
Sažetak
Početkom 2020. Hrvatska se suočila s pandemijom bolesti COVID-19. Pandemija se ubrzano širila što je dovelo do zatvaranja škola i fakulteta te se većinom organizirao prelazak na online nastavu. Na sreću, mnoge škole i fakulteti već su imali razrađene platforme za organizaciju nastave na daljinu. Tako je i na Libertas međunarodnom sveučilištu zbog pogoršane epidemiološke situacije obustavljena izravna kontaktna nastava u učionicama krajem ožujka 2020. Studenti, kao i nastavnici, u samom početku nisu bili pripremljeni na novi oblik nastave te je trebalo izvjesno vrijeme za prilagodbu. Iako su studenti i profesori raspolagali digitalnim kompetencijama i te vještine koristili u svakodnevnom životu i radu, ipak su nedostajale mnogim nastavnicima kod vođenja nastave, ali i studentima koji su trebali pratiti online predavanja i provoditi vježbe. Ukratko, riječ je o digitalnoj kompetenciji koju moraju u podjednakoj mjeri imati studenti i nastavnici. Na specijalističkom studiju na Libertasu provedena je anketa sa studentima, a pitanja su bila vezana uz digitalnu kompetenciju studenata, održavanje nastave na daljinu i ocjenjivanje studenata. Rezultati su predstavljeni u ovome radu.
\end{abstract}

Ključne riječi: online nastava, digitalne kompetencije, studenti, pandemija

\section{Uvod}

Početkom 2020. Republika Hrvatska se, kao i sav svijet, suočila s dosad nepoznatim virusom, odnosno pandemijom bolesti COVID-19. Uz nove, dosad gotovo nepoznate okolnosti, promijenile su se svakodnevne navike i ponašanja. Preko noći morali smo se prilagoditi novim mjerama kojima je ograničeno kretanje, propisana je obveza nošenja maske, dezinficiranja prostora, bilo je važno čuvati druge i sebe. Kako se pandemija širila, sve se više ljudi razboljelo pa i umiralo, neke tvrtke su zatvorene, ugostiteljski objekti nisu radili, organiziran je rad u timovima ili od kuće. Bez obzira na

mr. sc. Mladen Ilić, viši predavač na Libertas međunarodnom sveučilištu, mladen.ilic@gmail.com 
poduzete mjere pandemija se širila, što je ubrzo dovelo do zatvaranja škola i fakulteta te se većinom organizirao prelazak na online nastavu. Na sreću, mnoge škole i fakulteti već su imali razrađene platforme za organizaciju nastave na daljinu ili su do tada provodile online seminare ili neke druge oblike učenja na daljinu. Bez obzira na djelomičnu solidnu tehnološku i ostalu pripremljenost pandemija je izazvala „krizu na globalnoj razini i stvorila najveći poremećaj u obrazovanju u povijesti” (Kučina Softić, pristup 2021). Studenti iz Zagreba i okolice imali su dodatne otežavajuće okolnosti da se neposredno nakon pandemije dogodio i potres, koji je dodatno uznemirio studente, ali i oštetio javne ustanove, a među njima određeni broj škola i visokoobrazovnih institucija. Usprkos svemu, ubrzo se uspjela organizirati nastava, održavati konzultacije i vježbe te provoditi ispite na fakultetima. Tako je i na Libertas međunarodnom sveučilištu zbog pogoršane epidemiološke situacije obustavljena izravna kontaktna nastava u učionicama krajem ožujka 2020. Studenti i profesori promptno su obaviješteni da se sva predavanja, konzultacije, ispiti, obrane završnih i diplomskih radova na Libertasu obustavljaju, kao i fizički kontakti sa studentskom referadom i ostalim službama. Komunikacija s nastavnicima i stručnim službama obavljala se isključivo telefonskim i elektronskim putem (e-pošta i edunet). Također, sve su službe bile kontinuirano na raspolaganju putem tih komunikacijskih kanala.

Studenti, kao i nastavnici, u samom početku nisu bili pripremljeni na novi oblik nastave i trebalo je izvjesno vrijeme za prilagodbu. Iako su studenti i profesori raspolagali digitalnim kompetencijama i te su vještine koristili u svakodnevnom životu i radu, mnogima su postojeće bile nedovoljne kod vođenja nastave, a također i studentima koji su trebali pratiti online predavanja i provoditi vježbe.

Ukratko, riječ je o digitalnoj kompetenciji kojom moraju raspolagati u podjednakoj mjeri studenti i nastavnici. Uzaludno je da student ima znanja, vještine i iskustva rada na platformama za učenje, a da profesori svoja predavanja i vježbe na njima ne mogu provoditi. Stoga se provelo istraživanje o zadovoljstvu studenata sveučilišta Libertas za vrijeme pandemije bolesti COVID-19, a rezultate prikazujemo u ovome radu.

\section{Suvremeni učitelj/nastavnik i digitalna kompetencija}

Današnje društvo smatra odgoj i obrazovanje odgovornom i složenom ljudskom djelatnošću, a krajnji rezultat ovisi o mnogobrojnim čimbenicima, kako vanjskim tako i unutarnjim. Prenošenje znanja, učenje i poučavanje zahtjevan je, odgovoran i složeni zadatak nastavničke struke. Razvoj nove informacijsko-komunikacijske tehnologije nametnuo je novo obrazovanje i razvoj kompetencija novoga učitelja/nastavnika za 21. stoljeće. Budući da se 21. stoljeće smatra stoljećem znanja te da prodire u sve sfere ljudskog života, zadatak je profesionalnog obrazovnog kadra osposobiti mladi 
naraštaj da se uspješno snalazi i prilagođava nastupajućim i brzim promjenama. Znanje danas postaje glavni resurs razvoja društva, stoga suvremeni učitelj/nastavnik mora biti stručno osposobljen za cjeloživotno učenje koje teži permanentnom usavršavanju nastavničke struke. Trajno usavršavanje učitelja/nastavnika neprestano traje, stoga se za obrazovno osoblje kaže da su oni doživotni učenici (Barbieri, 2020).

Strategijom obrazovanja, znanosti i tehnologije Republike Hrvatske za razdoblje 2015. - 2025. (Ministarstvo znanosti, obrazovanja i sporta, 2015). kojom se obuhvaća područje cjeloživotnog učenja, mogu se izdvojiti sljedeće dominantne komponente: razvoj sposobnosti i potencijala pojedinaca, unapređenje sustava za profesionalni razvoj i usavršavanje nastavnika te poticanje na primjenu i modernizaciju informacijske i komunikacijske tehnologije u učenju i obrazovanju. Svaka je od tih komponenti međusobno ovisna. Modernizacija obrazovnog sustava nije moguća ako se ne ulaže u primjenu informacijske i komunikacijske tehnologije, a to sve ne bi bilo moguće bez profesionalnog razvoja nastavnika, odnosno razvoja njegovih kompetencija, kako digitalnih tako i svih ostalih.

\section{1. Što je digitalna kompetencija?}

Digitalna kompetencija najčešće je korišten koncept za opis tehnološki povezane vještine. Posljednjih godina koristilo se nekoliko naziva za opis kompetencije korištenja digitalnih tehnologija: IKT vještine, tehnološke vještine, vještine 21 . stoljeća, digitalne vještine, digitalna pismenost. Promjene u društvu i kulturi temeljene na novoj tehnologiji imaju utjecaja na nazivlje. Digitalna kompetencija sastoji se ne samo od digitalnih vještina, već i od socijalnih i emotivnih aspekata uporabe i razumijevanja digitalnih uređaja.

Digitalna kompetencija ključna je za učenje, rad i aktivno sudjelovanje u društvu. Za školsko obrazovanje nije važno samo razumjeti samu kompetenciju već je važno i znati kako pomoći razvijati tu kompetenciju. Također, to je jedna je od osam ključnih kompetencija i odnosi se na pouzdanu i ključnu uporabu cjelokupnog raspona digitalnih tehnologija za informacije, komunikaciju i za rješavanje osnovnih problema u svim aspektima života. (School Education Gateway, 2020).

Kao što je spomenuto, digitalna kompetencija iznimno je bitna u modernom globaliziranom svijetu, ali i pri korištenju raspoloživih alata za provođenje nastave na daljinu. Kako je ipak dolazilo do pritužbe nekih studenata da su se kod predavanja i provedbi vježbi uočili nedostaci digitalnih kompetencija kod nekih profesora, pojavila se potreba da se kroz istraživanje utvrdi, između ostaloga, i razina digitalne kompetencije kod nastavnika.

Nastavnici bi trebali biti nositelji promjena, imati veliku odgovornost za provedbu nastavnog procesa, za odabir pristupa poučavanju, što će u konačnici utjecati na 
studentova postignuća. Zbog toga je važno ulagati u razvoj nastavničkih kompetencija. Očekuje se da budu spremni prilagoditi se promjenama, da sami budu nositelji promjena i u skladu s time mijenjaju svoje uloge. Upravo je nastava na daljinu tijekom pandemije od nastavnika zahtijevala novu ulogu, stil vodstva te drugačiji pristup poučavanju. Tijekom akademske godine 2020./2021. (Zoretić et. al, 2021) proveli su istraživanje među nastavnicima triju visokoškolskih ustanova kojemu je cilj bio pokazati da se $\mathrm{u}$,uvjetima nastave na daljinu povećavanjem potreba za primjenom nastavničkih digitalnih kompetencija smanjuju potrebe za primjenom nastavničkih socijalnih kompetencija."

Glavni zaključci provedenog istraživanja vezano za digitalne kompetencije nastavnog osoblja bili su:

1. modernizacija obrazovnog sustava nije moguća, ukoliko se ne ulaže u primjenu informacijske i komunikacijske tehnologije, a to sve ne bi bilo moguće bez profesionalnog razvoja nastavnika, odnosno razvoja njegovih kompetencija, kako digitalnih tako i svih ostalih

2. ravnoteža između tih nastavničkih kompetencija, kontinuirano osnaživanje osobnih i socijalnih te usavršavanje stručnih i metodičkih kompetencija znatno će utjecati na cjeloviti razvoj i dobrobit studenata

3. u novonastalim uvjetima nastave na daljinu, u svrhu novih mogućnosti komuniciranja sa studentima, kod nastavnika dominira potreba za ulaganjem u razvoj digitalnih kompetencija.

Zaključak upozorava na to da digitalne kompetencije treba jačati i da su postale ključne nastavnicima i studentima.

Uvođenje novih tehnologija u nastavni proces ima svoje prednosti i nedostatke. Nove tehnologije mogu poučavanje i učenje u učionici (klasičnoj nastavi u živo, licem u lice) učiniti djelotvornijim, ali i pasivizirati studenta, ako je njegova aktivnost usmjerena samo na pamćenje onoga što je pokazano i izrečeno. Poučavanje i učenje na daljinu uz uporabu digitalne tehnologije može olakšati pristup znanju i umijećima svima i svugdje. No, za individualni razvoj studenata, posebice onih koji još nisu razvili samostalnost u učenju i pronašli vlastiti stil učenja, podrška nastavnika je ključna. Priprema ih za samostalnost u učenju, potiče ih na istraživanje i pronalaženje rješenja zadanih problema, a time im pomaže u stvaranju osobnih stavova i razvoju osobne odgovornosti (Zoretić et al., 2021: 90).

U odnosu na digitalnu kompetenciju učitelja i nastavnika, studije u tom području ponavljano ukazuju na nedostatak raspoloživog profesionalnog razvoja, osobito vezano uz korištenje informacijske i komunikacijske tehnologije za pedagoške svrhe. Isto tako, prilike za poboljšanje vlastitih kompetencija učitelja i nastavnika vezano uz korištenje informacijske i komunikacijske tehnologije prilično su rijetke te iskorištavanje prilika za informalno učenje stoga može biti korisno za učitelje i nastavnike. 
Iz dosad navedenog možemo potvrditi da je digitalna kompetencija ključna za sudjelovanje u današnjem društvu i gospodarstvu. Kao transverzalna kompetencija, digitalna kompetencija također pomaže u svladavanju drugih ključnih kompetencija kao što su komunikacija, jezične vještine ili osnovne vještine u području matematike i prirodoslovlja.

\subsection{Kako se razvija digitalna kompetencija u Europi}

U izvješću mreže Eurydice iz 2012. navodi se da gotovo sve europske zemlje imaju određene nacionalne strategije povezane s digitalnom kompetencijom. U vrijeme studije, digitalna kompetencija podučavala se međukurikularnim pristupom na osnovnoškolskoj razini u svim zemljama EU-a, osim u dvjema zemljama te na srednjoškolskoj razini u svim zemljama, uz ostale pristupe koji su se upotrebljavali u nekoliko zemalja, kao što je na primjer uključivanje informacijske i komunikacijske tehnologije u određene predmete ili podučavanje IKT-a kao zasebnog predmeta.

Ključni je čimbenik nastavnicima omogućiti dovoljnu razinu digitalne kompetencije. U studiji Međunarodno istraživanje učenja i poučavanja (engl. Teaching and Learning International Survey - TALIS) koja se provodi u zemljama članicama Organizacije za ekonomsku suradnju i razvoj (OECD) i partnerskim zemljama u petogodišnjim ciklusima, navodi se da je $18 \%$ osposobljavatelja i nastavnika izjavilo kako treba više razviti vještine u području IKT-a za potrebe nastave, a $16 \%$ za potrebe korištenja novih tehnologija na radnom mjestu.

Također, Europska komisija potvrdila je razvoj digitalne kompetencije kao relevantan prioritet politika Europske unije (Europska komisija, 2021). Sudjelovanje u društvu danas zahtijeva skup kompetencija povezanih s tehnologijom koje se prepoznaju kao i „životne vještine.” Potrebna je digitalna inkluzija koja ovisi o pristupačnosti i mogućnosti, ali i o znanju, vještinama i stavovima. A to se uči i razvija kroz digitalnu kompetenciju.

Digitalna kompetencija - odnosi se na osposobljenost za sigurnu i kritičku upotrebu informacijsko-komunikacijske tehnologije za rad, u osobnomu i društvenomu životu te u komunikaciji. Njezini su ključni elementi osnovne informacijsko-komunikacijske vještine i sposobnosti: upotreba računala za pronalaženje, procjenu, pohranjivanje, stvaranje, prikazivanje i razmjenu informacija te razvijanje suradničkih mreža putem interneta (Anđelić i Filipović Tretinjak, pristup 2021).

1 Obrazovna informacijska mreža koju financira Europska komisija (https://www.eurydice.hr/hr/ sadrzaj/mreza-eurydice/). 


\subsection{Istraživanje o studentskom životu u doba pandemije}

Istraživanje Europske studentske unije u suradnji sa Sveučilištem u Zadru, Institutom za razvoj obrazovanja te Ministarstvom znanosti i obrazovanja obuhvatilo je više od 9000 studenata, a rezultiralo je zanimljivim rezultatima o prilagodbi studenata na studij tijekom COVID-19 pandemije, utjecaju pandemije na nastavu i ocjenjivanje, radnom opterećenju studenata, utjecaju na njihove društvene mreže i emocionalnu stabilnost, utjecaju na studentske financije, mogućnost rada uz studiranje te dostatnost studentskih vještina i infrastrukture potrebne za studiranje od kuće.

\subsubsection{Rezultati istraživanja (obrazloženje)}

Pandemija COVID-19 koja je zahvatila Europu promijenila je mnoge aspekte života, od radnih uvjeta do slobode kretanja. Obrazovanje je bio jedan od sektora poremećen krizom s obrazovnim uslugama u Europi i na globalnoj razini otišao je na mrežu. U visokom obrazovanju, s jedne strane, taj novi trenutak je istaknuo određene prednosti online studiranja, uključujući niže životne troškove za studente, koji bi inače studirali daleko od svoje obiteljske kuće. S druge strane, naglasile su se nejednakosti između učenika, posebno u odnosu na razlike u smislu digitalnih vještina, mreža podrške resursa za rad i kućno okruženje.

Izvješće predstavlja uvid u studentska iskustva tijekom izolacije zbog COVID-19 pandemije na temelju odgovora na upitnike koje su u travnju dali studenti koji studiraju u Europi 2020. Istraživanje se usredotočilo na sposobnosti učenika, shvaćene kao raznolika skupina, da imaju razumno pozitivne akademske rezultate u kontekstu katastrofe kao što je COVID-19 pandemija, kao i ulogu njihovog akademskog okruženja, društvenih mreža, emocionalnih stanja, znanja i vještina te materijalnih resursa za omogućavanje takvih iskustava. Na kraju izvješća pruža se uvid u odgovore učenika na otvorena pitanja koja obuhvaćaju prednosti i nedostatke mrežnog učenja tijekom pandemije te probleme s kojima su se studenti susreli i prijedloge za poboljšanje.

1. Predavanja

Studenti su bili izloženi različitim formatima koji su zamijenili predavanja: online nastava kada nastavnik predaje u stvarnom vremenu $(74,61 \%)$, nastavnici šalju svoja izlaganja studentima $(44,51 \%)$ sa online video zapisom predavanja nastavnika $(32,10 \%)$ i online s glasovnim zapisom nastavnika $(20,58 \%)$. Za vrlo mali broj studenata $(3,75 \%)$ nisu organizirana online predavanja. Najčešće su organizirana online predavanja u stvarnom vremenu $(59,73 \%)$. Većina studenata preferirala je online predavanja te kada nastavnik predaje u stvarnom vremenu (57,43 \%), što implicira da većina studenata voli imati interakciju nastavnik - student.

\section{Seminari}

Studenti su bili izloženi raznim formatima koji su zamijenili seminare na licu mjesta: 
- online s nastavnikom koji predaje u stvarnom vremenu $(45,09 \%)$

- kroz pisanu komunikaciju s nastavnikom (26,76\%)

- online s videosnimkom predavanja nastavnika $(12,51 \%)$ i

- online s audiosnimkom predavanja (7,9\%).

Dominantna metoda održavanja seminara bila je online s uključenim nastavnikom u stvarnom vremenu (38,03 \%). U odnosu na predavanja, veći udio studenata (15\%) izvijestio je da nije bilo online održavanja njihovih seminara. Kao i kod predavanja, studenti preferiraju metodu online seminara s uključenim nastavnikom.

\section{Praktična nastava}

Studenti su bili izloženi različitim formatima koji su odmah zamijenili praktičnu nastavu licem o lice: online s nastavnikom koji predaje u stvarnom vremenu (41,77\%), putem pisane komunikacije s nastavnikom (23,01\%), online s videozapisom nastavnika (12,56 \%) i online sa zvučnim zapisom nastavnika (6,18 \%). Dominantni format bio je online s predavačem uključenim u stvarnom vremenu (37,9\%). Za $20,23 \%$ učenika, odnosno petinu učenika nije bilo online pružanja praktične nastave. Opet, baš kao i s predavanjima, preferirana metoda je s nastavnikom uključenim u stvarnom vremenu. U svim oblicima poučavanja poželjan način isporuke sadržaja je s nastavnikom emitirano u stvarnom vremenu.

\section{Ocjena}

Za trećinu učenika nije bilo planiranih nadzora za taj oblik. Kada su nadzori bili organizirani imali su različite oblike: putem e-pošte (52,9 \%), putem videopoziva (36,87 \%), putem glasovnog poziva (13,74\%). Studenti preferiraju format nadzora putem videopoziva što dodatno potvrđuje da studenti preferiraju interakciju licem u lice s nastavnim osobljem. U prosjeku su se studenti složili da su njihovi nastavnici davali zadatke iz kolegija redovito, pravovremeno i odgovarali na njihova pitanja i bili otvoreni za komunikaciju.

\section{Glavni rezultati}

Studenti su prihvatili i prilagodili se online provedbi nastave. Složili su se da su predavači dali povratne informacije njihovim zadacima te informirali studente kako će njihovi ispiti izgledati u novonastaloj situaciji.

\section{Podrška okoline}

Studenti će razgovarati sa svojom obitelji o krizi COVID-19, a isto tako i s bliskim prijateljema. Mali dio studenata bi se okrenuo institucionalnim izvorima podrške. Tijekom pandemije bolesti COVID-19 učenici su svakodnevno komunicirali sa svojom užom obitelji i bliskim prijateljima. Također su imali tjednu komunikaciju s kolegama i nastavnicima. Komunikacija s administrativnim osobljem bila je znatno rjeđa. 9,1 \% učenika navelo je da nema u svojoj okolini ljude kojima bi mogli vjerovati da će im pomoći u rješavanju njihovih problema. Studenti koji su živjeli u svojim obiteljskim kućama izvijestili su o većoj razini društvenog povezivanja u odnosu na 
studente koji su živjeli u iznajmljenom ili studentskom smještaju. Također, učenici koji su se razboljeli izjavili su da su imali slabiju povezanost sa drugima. Opći je zaključak za taj dio da se za mnoge probleme koje studenti mogu imati ne treba oslanjati na institucionalna rješenja.

\section{Emocionalna stanja}

Studenti su se često osjećali frustrirano, tjeskobno i dosadno zbog nedostatka uobičajenih aktivnosti za vrijeme studiranja zbog prelaska na online nastavu. Rezultati pokazuju da su tijekom pandemije bolesti COVID-19 studenti bili pogođeni, a to se manifestiralo naročito kod siromašnijih studenata koji su imali poteškoće s plaćanjem troškova studija, studenata s emocionalnim problemima i studenata koji nemaju mirno mjesto za učenje. Novonastala situacija je posebno uznemirila studente koji nemaju uz sebe prijatelje i bližu obitelj koja ih podržava.

\section{Vještine i infrastruktura za učenje od doma}

Većina studenata (80,7 \%) osjeća se sigurnim u korištenju internetskih platformi za poučavanje kao MsTeams, Zoom i slično. Međutim, 7,9 \% je izrazilo nedostatak povjerenja u upotrebu online nastavnih platformi. Kao što se moglo očekivati, studenti s područja inženjerstva, proizvodnje i građevinarstva imaju višu razinu digitalnog znanja u odnosu na sve ostale skupine studenata. Studenti koji su imali zdravstvene probleme imali su manje digitalnih vještina. Većina studenata ima vlastito računalo $(89,3 \%)$, međutim samo $41 \%$ je izjavilo da uvijek imaju dobru internetsku vezu. Samo $0,5 \%$ nema svoje vlastito računalo. Većina studenata često ili uvijek ima mirno mjesto za rad i učenje, a 3,3 \% studenata nema mirno mjesto za učenje. Većina ih ima radni stol (79,2 \%), ali 3,2 \% učenika nema stol za rad. Samo trećina studenata je izjavila da uvijek imaju pristup materijalima za učenje kolegija.

\section{9. Životne okolnosti}

Više od četvrtine učenika navelo je da je najviše zabrinuto za svoje zdravlje. Usklađivanje odgovornosti za studiranje, kao i životni troškovi navelo je većinu na to da su cijelo vrijeme bili zabrinuti. Oni koji su živjeli u unajmljenom smještaju i studentskom domu izjavili su veću zabrinutost oko troškova studiranja i života u usporedbi sa studentima koji živjeli u svojim obiteljskim kućama ili nekom drugom smještaju. Stariji i izvanredni studenti, studenti koji ne plaćaju školarinu kao i studenti koji su izjavili zdravstvene probleme u većoj su mjeri zabrinuti zbog svojih troškova studiranja i života.

10. Rad i učenje

Od studenata koji su radili ili su planirali raditi za vrijeme pandemije, 28,9\% privremeno je izgubilo posao, dok je 12,2 \% trajno ostalo bez posla. Studenti kojima je rad nužan za podmirenje troškova studiranja i života izloženi su većem riziku. Doista, studenti koji su trajno izgubili posao teže su podmirivali troškove studiranja i života u usporedbi sa svim ostalim studentima. 


\section{1. Školarina}

Za studente koji plaćaju školarinu, većina $(75,3 \%)$ je odgovorila da im je iznos školarine ostao isti. Neki studenti (13,8 \%) imali su fleksibilniji načini plaćanja školarine, a 1,8 \% je izjavilo da njihov fakultet nije naplatio školarinu za tekući semestar.

\section{Stipendije}

Za studente koji primaju stipendije većina $(87,4 \%)$ je odgovorila da je iznos njihovih stipendija ostao isti. Međutim, za gotovo desetinu studenata kriza je imala negativan utjecaj na njihov status stipendije i isplatu stipendije koja je bila odgođena (4,10\%), otkazana (2,9\%) ili smanjena (2,6\%).

\section{Zadovoljstvo nastavom $i$ administracijom}

Studenti su uglavnom bili zadovoljni nastavnicima koji su provodili online nastavu. Manje su bili zadovoljni organizacijom provedbe seminara i praktične nastava. U prosjeku, stariji studenti, koji su imali veće mogućnosti podmirivanja troškova studiranja i života kao i oni koji nisu plaćali školarinu, kao i izvanredni studenti, bili su zadovoljniji. Osim toga, veću razinu zadovoljstva nastavom i administracijom potvrdili su studenti koji nisu patili od neke kronične bolesti, mentalnih ili drugih zdravstvenih problema, kao i studenti koji su stanovali blizu fakulteta. Konačno, studenti koji su se bolje služili računalnom opremom te koji su bili bolje povezani s drugim studentima, ali i oni koji su manje brinuli o troškovima i zdravlju također su bili zadovoljniji.

\section{Prilagođavanje učenika}

$47,43 \%$ učenika navelo je da su imali slabiji uspjeh s obzirom na to da je nastava licem u lice u učionici otkazana. Općenito, nakon što se statistički kontroliraju svi drugi prediktori, mlađi studenti, studenti koji nemaju mirno mjesto za učenje, dobru internetsku vezu i materijal za studiranje koji im je na raspolaganju, kao i studenti s nižim razinama digitalnog i društvenog kapitala, dosljedno su potvrđivali nižu prilagodbu tijekom pandemije bolesti COVID-19 i izolacije. Osim toga, studenti koji su izvijestili o problemima s mentalnim zdravljem dosljedno su imali niže ocjene po svim pokazateljima.

\section{Istraživanje provedeno na specijalističkom studiju Libertas međunarodnog sveučilišta}

Nakon provedenog istraživanja na trima visokoškolskim ustanovama vezano za profesore, napravljeno je i istraživanje na specijalističkom studiju Sveučilišta Libertas. U anketi je sudjelovalo 70 studenata. Uzimajući u obzir podatke istraživanja koja su provedena s predavačima/nastavnicima i studentima o tome kako je bilo raditi i učiti, ali i kakvi su bili socijalni kontakti između studenata i profesora, napravljena je i anketa 
sa studentima specijalističkih studija sveučilišta Libertas. ${ }^{2} \mathrm{U}$ anketi je sudjelovalo 70 studenata, a cilj je bio saznati koje su probleme studenti imali vezano za studiranje, polaganje ispita te druženje s nastavnicima i studentima u uvjetima pandemije tijekom akademske godine 2020./2021. Pitanja u anketi bila su usmjerena na digitalnu kompetenciju studenata, održavanje nastave na daljinu, ocjenjivanje studenata i ostala pitanja. Anketa je koncipirana tako da se može na nju odgovoriti u relativno kratkom roku od desetak minuta.

Prvi set pitanja sa zajedničkim nazivnikom „digitalna kompetencija” trebao je dati odgovor na pitanje kako su se studenti snašli u procesu provedbe nastave na daljinu. Radi jasnoće: „nastava na daljinu je oblik učenja i poučavanja u kojemu se ne ostvaruje fizička prisutnost učenika i učitelja, već se proces učenja i poučavanja odvija u virtualnom okruženju uz podršku digitalnih tehnologija" (Carnet, pristup 2021). Anketni upitnik sastojao se od 18 pitanja koja su imala tri moguća odgovora, a popunjavali su ga anonimno. U nastavku su pitanja, odgovori i komentari rezultata.

\begin{tabular}{ccc}
\hline Prvo pitanje & Odgovor & $\%$ \\
\hline & Nikada & 67,7 \\
\hline $\begin{array}{c}\text { Prije početka pandemije sudjelovao sam u nekim oblicima } \\
\text { nastave na daljinu (online seminari, radionice, predavanja) }\end{array}$ & $\begin{array}{c}\text { Do } 3 \text { radionice ili } \\
\text { seminara }\end{array}$ & 17,6 \\
\hline & 4 i više puta & 14,7 \\
\hline
\end{tabular}

Na prvo pitanje vezano za prijašnje iskustvo sudjelovanja na nekim oblicima nastave (online seminari, radionice, predavanja) čak 67,7 \% studenata izjavilo je da nikada nije sudjelovalo na online seminarima, radionicama ili predavanjima. Tek svaki sedmi student potvrdio je da je više puta sudjelovao na takvom obliku prijenosa znanja. Temeljem dobivenih odgovora na anketno pitanje bez obzira na to što studenti uspješno koriste pametne mobitele, računala i ostalu elektronsku tehniku komuniciranja, iznenađujuće velik broj studenata nije sudjelovalo u nekim oblicima nastave na daljinu. Nedostatak iskustva sudjelovanja u nastavi na daljinu može dovesti do toga da se ne shvaća jednako ozbiljno kao nastava koja se odvija u učionicama. Također, nastava na daljinu zahtijeva od studenata samodiscipliniranost i dobru organizaciju vremena koju često studenti nemaju. Potrebno je tu vrstu nastave shvatiti ozbiljno kao da se odvija na fakultetu.

\begin{tabular}{|c|c|c|}
\hline Drugo pitanje & Odgovor & $\%$ \\
\hline \multirow{3}{*}{$\begin{array}{l}\text { Sa svojom digitalnom kompetencijom, odnosno } \\
\text { korištenjem digitalnih tehnologija sam }\end{array}$} & Zadovoljan & 92,1 \\
\hline & $\begin{array}{l}\text { Ni zadovoljan, ni } \\
\text { nezadovoljan }\end{array}$ & 6,8 \\
\hline & Nezadovoljan & 1,1 \\
\hline
\end{tabular}

2 Rad nije nastavak rada „Transformacijska uloga nastavnika u uvjetima nastave na daljinu” objavljenog također u ovome Zborniku, u kojoj je sudjelovalo nastavno osoblje sveučilišta Libertas, nego prikaz istraživanja koje je provedeno sa studentima na sveučilištu Libertas. 
Više od $92 \%$ anketiranih studenata izjavilo je da je jako zadovoljno svojom digitalnom kompetencijom. Takvi odgovori upućuju na to da bi se, ukoliko se organiziraju različiti vidovi edukacije preko jedne od primjenjivih platformi za učenje na daljinu, studenti jako dobro snašli. Možemo pretpostaviti da će se i bez obzira na pandemiju studenti sve više koristiti digitalnim tehnologijama, pogotovo na društvenim mrežama Facebooku, Instagramu i Twiteru.

\begin{tabular}{c|cc}
\hline Treće pitanje & Odgovor & $\%$ \\
\hline \multirow{3}{*}{ Sa računalnom opremom koju posjedujem sam } & Zadovoljan & 85,2 \\
\cline { 2 - 3 } & $\begin{array}{c}\text { Ni zadovoljan, ni } \\
\text { nezadovoljan }\end{array}$ & 14,1 \\
\hline & Nezadovoljan & 0,7
\end{tabular}

Treće pitanje odnosilo se na zadovoljstvo studenata računalnom opremom koju studenti posjeduju. Velika većina studenata $(85,2 \%)$ zadovoljna je jer ispunjava sve tehničke preduvjete za uspješno sudjelovanje u procesu učenja. Samo jedan student je odgovorio da je nezadovoljan opremom koju posjeduje, a ostatak od 14,1 \% odgovorio je da su donekle zadovoljni opremom i tehničkom uslugom kojom raspolažu.

\begin{tabular}{c|cc}
\hline Četvrto pitanje & Odgovor & $\%$ \\
\hline \multirow{2}{*}{ S tehničkom i administrativnom podrškom sveučilišta sam } & $\begin{array}{c}\text { Zadovoljan } \\
\text { Ni zadovoljan, ni } \\
\text { nezadovoljan }\end{array}$ & 80,1 \\
\cline { 1 - 2 } & Nezadovoljan & 19,1 \\
\hline
\end{tabular}

Sljedeće pitanje bilo je vezano uz tehničku i administrativnu podršku sveučilišta. Više od 80 \% studenata je izjavilo da je sveučilište Libertas sa svoje strane ispunilo u potpunosti potrebne tehničke i administrativne uvjete za odvijanje nastave na daljinu. Ohrabruje da ni jedan od studenata nije u anketi odgovorio da je nezadovoljan, a $20 \%$ je prema pristiglim odgovorima odgovorilo da fakultet donekle ispunjava potrebne preduvjete. Kako je velika većina studenata potvrdila da je sveučilište Libertas poduzelo dovoljno da studenti imaju tehničku i administrativnu podršku, možemo utvrditi da je studentima osigurano da mogu redovito i sigurno pratiti nastavu.

\begin{tabular}{ccc} 
Peto pitanje & Odgovor & $\%$ \\
\hline $\begin{array}{c}\text { Potrebna literatura i ostali materijali potrebni za praćenje } \\
\text { nastave i sudjelovanje na vježbama bili su u elektronskom } \\
\text { obliku }\end{array}$ & Dostupni & 84,1 \\
\cline { 2 - 3 } & Djelomično dostupni & 15,9 \\
\hline
\end{tabular}

Na pitanje jesu li potrebna literatura i ostali radni materijali potrebni za praćenje nastave dostupni, 84,1 \% izjavilo je da su u cijelosti dostupni, dok je 15,9 \% izjavilo da nisu u potpunosti dostupni. Ipak, ni jedan odgovor ne implicira da su potrebna literatura i materijali za vježbe bili nedostupni. 


\begin{tabular}{|c|c|c|}
\hline Šesto pitanje & Odgovor & $\%$ \\
\hline \multirow{3}{*}{$\begin{array}{c}\text { Profesori i ostalo nastavno osoblje odlično su se služili } \\
\text { digitalnim alatima u nastavi na daljinu }\end{array}$} & Slažem se & 67,2 \\
\hline & Djelomično se slažem & 31,4 \\
\hline & Ne slažem se & 1,4 \\
\hline
\end{tabular}

Sljedeće pitanje bilo je vezano uz digitalnu kompetenciju nastavnog osoblja i jesu li se odlično služili s dostupnim alatima u nastavi na daljinu. Velika većina studenata $(67,2 \%)$ je odgovorila da su se nastavnici odlično služili raspoloživim alatima, dok je $31,4 \%$ utvrdilo da se djelomično slažu. Samo jedan student naveo je da se nastavnici nisu dobro snašli u novonastaloj situaciji. Podaci dobiveni odgovorima studenata na to pitanje ukazuju da su u velikom postotku nastavnici savladali digitalne tehnike korištene za vrijeme predavanja i provedbi vježbi.

\begin{tabular}{ccc} 
Sedmo pitanje & Odgovor & $\%$ \\
\hline \multirow{3}{*}{ S predavanjima i vježbama u nastavi na daljinu bio sam } & Zadovoljan & 73,3 \\
\cline { 2 - 3 } & Djelomično zadovoljan & 23,8 \\
\cline { 2 - 3 } & Nezadovoljan & 2,9
\end{tabular}

Zaključno, što se tiče zadovoljstva studenata s predavanjima i provedbom vježbi, velika većina od 73,3 \% izjavila je da su bili zadovoljni, 23,8 \% djelomično zadovoljni, a samo $2,9 \%$ je ostalo nezadovoljno provedenim predavanjima i vježbama.

\begin{tabular}{ccc} 
Osmo pitanje & Odgovor & $\%$ \\
\hline $\begin{array}{c}\text { Profesori i ostalo nastavno osoblje uveli su nove načine } \\
\text { predavanja i provedbi vježbi }\end{array}$ & Slažem se & 63,3 \\
\cline { 2 - 3 } & Djelomično se slažem & 33,8 \\
\cline { 2 - 3 } & Ne slažem se & 2,9
\end{tabular}

Na pitanje jesu li nastavnici bili inovativni i kreativni, odnosno jesu li iskoristili mogućnost platforme i uveli nove načine predavanja i provedbi vježbi, 63,3 \% je zaključilo da su se nastavnici dobro snašli u novonastaloj situaciji i uveli nove načine i da je nastava bila drugačija i kreativnija. Ipak, gotovo $3 \%$ studenata nije bilo zadovoljno s prilagodbom profesora, odnosno prema njihovom mišljenju, nisu u dovoljnoj mjeri bili kreativni.

\begin{tabular}{ccc}
\hline Deveto pitanje & Odgovor & $\%$ \\
\hline $\begin{array}{c}\text { Profesori su bili dostupni na konzultacijama u nastavi na } \\
\text { daljinu }\end{array}$ & Slažem se & 88,6 \\
\cline { 2 - 3 } & Djelomično se slažem & 10,0 \\
\cline { 2 - 3 } & Ne slažem se & 1,4
\end{tabular}

Što se tiče konzultacija i dostupnosti profesora, 88,6 \% studenata je odgovorilo da su profesori bili dostupni u dogovoreno i unaprijed objavljeno vrijeme održavanja konzultacija. $10 \%$ ih je odgovorilo da nije do kraja precizno usuglašeno vrijeme konzultacija, a samo 1,4 \% studenata je odgovorilo da su im konzultacije bile nedostupne. 


\begin{tabular}{ccc}
\hline Deseto pitanje & Odgovor & $\%$ \\
\hline \multirow{2}{*}{$\begin{array}{c}\text { Profesori su na početku nastave na daljinu jasno precizirali } \\
\text { način na koji će ocjenjivati studente }\end{array}$} & Slažem se & 82,6 \\
\cline { 2 - 3 } & Djelomično se slažem & 14,3 \\
\hline
\end{tabular}

Kako znamo da se prelaskom na online nastavu dosta toga promijenilo, pa tako i način ocjenjivanja studenata, utvrđeno je da su studenti u velikom postotku $(82,6 \%)$ znali, odnosno bio im je jasno preciziran način na koji će se ocjenjivati. Ipak, 3,1 \% studenata bilo je nezadovoljno, a njih više od $14 \%$ djelomično se slaže da je jasno preciziran način ocjenjivanja.

\begin{tabular}{c|cc}
\hline Jedanaesto pitanje & Odgovor & $\%$ \\
\hline Kriteriji ocjenjivanja bili su & $\begin{array}{c}\text { Stroži od najavljenog } \\
\text { Očekivani i u skladu s } \\
\text { najavljenim }\end{array}$ & 87,0 \\
\hline Blaži od najavljenog & 2,1
\end{tabular}

Sljedeće pitanje bilo je vezano za kriterij ocjenjivanja. 90 \% studenata je navelo da su kriteriji ocjenjivanja bili očekivani i u skladu s najavljenim, a samo 2,1 \% je napisao da su kriteriji bili blaži od najavljenog.

\begin{tabular}{ccc}
\hline Dvanaesto pitanje & Odgovor & $\%$ \\
\hline $\begin{array}{c}\text { Na ispitu na daljinu imao sam veću mogućnost korištenja } \\
\text { nedozvoljenih metoda (prepisivanje) }\end{array}$ & Slažem se & 5,7 \\
\cline { 2 - 3 } & Djelomično se slažem & 31,4 \\
\hline
\end{tabular}

Na pitanje kojim se željelo utvrditi jesu li studenti imali veću mogućnost korištenja nedozvoljenih metoda (npr. prepisivanje) mali dio, svega $6 \%$ je odgovorilo da jesu, djelomično se $s$ tom tvrdnjom složilo $31,4 \%$ studenata, a većina od gotovo $70 \%$ nije se složila s pretpostavkom da su imali više mogućnosti korištenja nedozvoljenih sredstava.

\begin{tabular}{ccc} 
Trinaesto pitanje & Odgovor & $\%$ \\
\cline { 2 - 3 } Više mi odgovara nastava na daljinu nego klasična nastava & Slažem se & 61,4 \\
\cline { 2 - 3 } & Djelomično se slažem & 22,9 \\
\cline { 2 - 3 } & Ne slažem se & 15,7
\end{tabular}

Iako je spomentuo da u doba pandemije profesorima, a isto tako i studentima, nedostaje socijalna komponenta studiranja, odnosno druženje, razgovor, razmjena iskustva i neposredni socijalni dodir, $62 \%$ studenata je odgovorilo da im odgovara nastava na daljinu više nego klasična nastava. Čak je $22 \%$ studenata odgovorilo da se djelomično slaže s navedenom pretpostavkom, a samo $15 \%$ studenata izjasnilo se da im više odgovara klasična nastava. 


\begin{tabular}{ccc}
\hline Četrnaesto pitanje & Odgovor & $\%$ \\
\hline $\begin{array}{c}\text { Na ispitu (međuispitu) u nastavi na daljinu imao sam } \\
\text { dovoljno vremena za pripremu odgovora }\end{array}$ & Slažem se & 45,7 \\
& Djelomično se slažem & 38,2 \\
\hline Petnaesto pitanje & Ne slažem se & 16,1 \\
\hline \multirow{2}{*}{$\begin{array}{c}\text { U odnosu na klasičnu nastavu najviše mi nedostaje } \\
\text { neposredni kontakt sa profesorima }\end{array}$} & Odgovor & $\%$ \\
\cline { 2 - 3 } & Slažem se & 25,7 \\
& Djelomično se slažem & 56,8 \\
\hline
\end{tabular}

Na sljedeće pitanje kojim se željelo utvrditi nedostaje li studentima neposredni kontakt s profesorima, samo $25,7 \%$ studenata je potvrdilo da im nedostaje neposredni kontakt, ali je i $17 \%$ potvrdilo da im neposredni kontakt ne nedostaje. Većina od $56 \%$ studenata izjasnila se da se djelomično slaže da im najviše u odnosu na klasičnu nastavu nedostaje neposredni kontakt sa profesorima. Pretpostavka može biti da se sa manjim prekidima, nakon gotovo 18 mjeseci održavanja nastave na daljinu izgubila socijalna potreba neposrednog kontakta s drugim osobama. Također, studenti nisu mogli osobno ni upoznati mnoge profesore koji su predavali na daljinu, tako da se nije razvila potreba za druženjem u učionicama.

Također, nakon ankete mišljenja smo da je trebalo postaviti pitanje „u odnosu na klasičnu nastavu nedostaje mi neposredni kontakt sa profesorima”, odnosno maknuti riječ „najviše”, naročito zbog toga jer je u sljedećem pitanju bilo postavljeno „u odnosu na klasičnu nastavu najviše mi nedostaje neposredni kontakt s ostalim kolegama i studentima."

\begin{tabular}{ccc} 
Šesnaesto pitanje & Odgovor & $\%$ \\
\hline $\begin{array}{c}\text { U odnosu na klasičnu nastavu najviše mi nedostaje } \\
\text { neposredni kontakt sa ostalim kolegama i studentima }\end{array}$ & Slažem se & 47,1 \\
\cline { 2 - 3 } & Djelomično se slažem & 36,8 \\
\hline & Ne slažem se & 16,1
\end{tabular}

Na pitanje nedostaje li studentima neposredni kontakt s drugim studentima, $47,1 \%$ je odgovorilo da im nedostaje neposredni kontakt, a djelomično se ložilo $36 \%$ studenata. Samo $16 \%$ je odgovorilo da nisu osjetili potrebu za neposrednim kontaktom s drugim studentima.

\begin{tabular}{ccc} 
Sedamnaesto pitanje & Odgovor & $\%$ \\
\hline $\begin{array}{c}\text { Studentska referada je u potpunosti bila dostupna } \\
\text { studentima }\end{array}$ & Slažem se & 77,6 \\
& Djelomično se slažem & 18,1 \\
& Ne slažem se & 4,3
\end{tabular}

Budući da studentska referada obavlja administrativne poslove vezano uz studente na fakultetu, ali je i mjesto gdje studenti često zalaze zbog raznih upita, anke- 
tom je bilo postavljeno pitanje ,je li studentska referada bila u potpunosti dostupna studentima." Većina od 78 \% potvrdila je da je referada u potpunosti obavila funkciju „žarišne točke” potrebne pomoći studentima, dok se samo $4 \%$ nije složilo s takvom konstatacijom. Ipak, 18 \% studenata se djelomično složilo da je referada u potpunosti ispunila svoju ulogu.

\begin{tabular}{ccc} 
Osamnaesto pitanje & Odgovor & $\%$ \\
\hline $\begin{array}{c}\text { Rad u nastavi na daljinu uzrokuje mi manji psihološki stres } \\
\text { od rada u klasičnoj nastavi }\end{array}$ & Slažem se & 58,6 \\
\cline { 2 - 3 } & Djelomično se slažem & 17,1 \\
\hline & Ne slažem se & 24,3
\end{tabular}

Zadnje anketno pitanje propituje je li studentima nastava na daljinu uzrokovala „manji psihološki stres” za razliku od klasične nastave, a čak 58 \% studenata potvrdilo je tu pretpostavku. Jedna četvrtina iskazala je da nisu imali nikakav problem s prelaskom na nastavu na daljinu, a djelomično se složilo sa tvrdnjom $17 \%$ studenata.

\section{Zaključak}

Istraživanje koje je provedeno putem ankete sa studentima sveučilišta Libertas dalo je zanimljive odgovore. Prije početka nastave na daljinu gotovo $68 \%$ studenata nije nikada sudjelovalo u bilo kojim oblicima nastave na daljinu (online seminari, radionice, predavanja), iako je više od $92 \%$ zadovoljno svojim digitalnim kompetencijama, a $85 \%$ ih je zadovoljno svojom računalnom opremom. S tehničkom i administrativnom podrškom sveučilišta zadovoljno je više od $80 \%$ studenata. Više od $80 \%$ studenata ustvrdilo je da su literatura i ostali materijali potrebni za praćenje nastave i sudjelovanje na vježbama bili dostupni u elektronskom obliku. Dvije trećine studenata navelo je da su se profesori i ostalo nastavno osoblje odlično služili digitalnim alatima u nastavi na daljinu, a $73 \%$ studenata je zadovoljno s predavanjima i vježbama te je $63 \%$ potvrdilo da su profesori uveli nove načine predavanja i provedbi vježbi. Konzultacije su se uredno održavale što je potvrdilo $88,6 \%$ anketiranih studenata. Profesori su na početku nastave na daljinu jasno precizirali način na koji će ocjenjivati studente, što je potvrdilo 82,6 \% studenata, a kriteriji ocjenjivanja bili su očekivani i u skladu s najavljenim (87,9\%). Također, što se tiče mogućnosti korištenja nedozvoljenih metoda (prepisivanje) na ispitu na daljinu većina od 62,9 \% nije se složila da su mogli koristiti u punoj mjeri mogućnost „varanja” na ispitu. Na ispitu (međuispitu) u nastavi na daljinu gotovo $84 \%$ studenata se složilo da je imalo dovoljno vremena za pripremu odgovora. Malo iznenađenje je da je čak $61,4 \%$ studenata odgovorilo da im više odgovara nastava na daljinu, nego klasična nastava. Na pitanje nedostaje li im u odnosu na klasičnu nastavu neposredni kontakt s profesorima, samo 17,5 \% ispitanika je ustvrdilo da im taj kontakt nedostaje. Većina se studenata $(83,9 \%)$ u potpunosti ili 
djelomično složila s tvrdnjom da im je nedostajao socijalni kontakt s kolegama studentima. Studentska referada u potpunosti je bila dostupna studentima, što je ustvrdilo 77,6 \% studenata, a samo 4,3 \% nije zadovoljno dostupnošću referade. Da je studentima rad u nastavi na daljinu uzrokovao manji psihološki stres od rada u klasičnoj nastavi, potvrdilo je 58,6 \% studenata, a $24,3 \%$ studenata smatra da im je rad na daljinu uzrokovao manji stres.

Učenje na daljinu zahtijeva i od profesora i od studenata novi pristup. Smanjuje se socijalna dimenzija čitavog procesa, a povećava se potreba za digitalnim kompetencijama. Alati i platforme koje su na raspolaganju profesorima i studentima sve su razvijeniji i olakšavaju rad. Najvažnije trendove vezane uz aspekt učenja istaknuo je Siemens (2004). Posebno je naglasio da će za životnoga vijeka veliki broj ljudi mijenjati područja rada i učenja. Zatim, da će neformalno učenje postati sve važnije (zahvaljujući različitim strukovnim zajednicama i socijalnim mrežama). Učenje je kontinuirani proces koji traje cijeli život. Učenje i aktivnosti vezane za posao više nisu razdvojene. Tehnologija utječe na naš mozak i mijenja ga. Razni alati kojima se koristimo definiraju i oblikuju naše razmišljanje, a tehnologija pruža potporu procesu učenja. Organizacije i pojedinci su učeći organizmi. Pozornost je usmjerena na teorije koje pokušavaju objasniti vezu između pojedinca i organizacije. Znati-kako i znati-što nadopunjuje se sa znati-gdje. Veoma važno postaje znanje o tome na kojim mjestima pronaći potrebne informacije (Siemens, 2004).

Međutim, danas sve više ističemo važnost međusobnog odnosa nastavnika i učenika, dvosmjernost komunikacije i dijalog kao temeljne pretpostavke suradnje i suodgovornosti. Pozitivno nastavno ozračje implicira potporu nastavnika učeniku u teškoćama, ali i visoke standarde u zahtjevima. Pozitivno nastavno ozračje može se održati samo ako nastava dobro funkcionira i ostvaruje očekivane ciljeve (Jelavić, 2003).

Akcijskim planom za digitalno obrazovanje nastoji se: ponuditi dugoročna strateška vizija za visokokvalitetno, uključivo i pristupačno europsko digitalno obrazovanje, svladati izazove i iskoristiti prilike proizašle iz pandemije bolesti COVID-19, tijekom koje se tehnologija u obrazovanju i osposobljavanju upotrebljavala više nego ikad prije, ojačati suradnja na razini EU-a u području digitalnog obrazovanja i istaknuti važnost međusektorske suradnje kako bi se obrazovanje prilagodilo digitalnom dobu, stvoriti nove prilike, uključujući bolju kvalitetu i ponudu digitalnih tehnologija za poučavanje, potporu digitalizaciji metoda poučavanja i pedagoških metoda te osiguravanje infrastrukture potrebne za uključivo i funkcionalno učenje na daljinu.

Može se zaključiti da je uvođenjem nastave na daljinu započeo proces promjena na području provođenja nastavničkih funkcija. No na žalost u praksi, u uvjetima nastave na daljinu, zbog intenzivne primjene digitalnih kompetencija, uspješna primjena socijalnih kompetencija nije došla dovoljno do izražaja. U tom kontekstu, osobito je važno da se nastavnik posveti i samomotivaciji za rad sa studentima, da mu 
poučavanje bude uvijek iznova izazov i prilika za poticanje osobnog i profesionalnog razvoja studenata s kojima je u interakciji, a također i prilika za stvaranje kvalitetnih međuljudskih odnosa iz kojih će proizaći stručnjaci sposobni stvarati neke nove vrijednosti i biti spremni na cjeloživotno učenje. Za kraj, citat iz Perkov (2019): „upravljanje promjenama nije nimalo lagana zadaća ali je umijeće koje se može naučiti! Može vam se spočitavati da ste tijekom implementacije bili suviše usredotočeni na zadaću ili proces. Da ste premalo komunicirali i konzultirali se, ili pak previše. Možda ste toliko jasno vidjeli sliku željenog novog stanja da ste zaboravili kreirati izlaze za slučaj nužde. Ili ste možda unijeli kaos u organizaciju jer te zanemarili utjecaj promjene na vaše okružje?"

\section{Literatura}

1. Anđelić, V. i Filipović Tretinjak, M. Digitalne kompetencije za nastavnike. chrome-extension://efaidnbmnnnibpcajpcglclefindmkaj/viewer.html?pdfurl=https\%3A \%2F\%2Fradovi2015.cuc.carnet.hr\%2Fmodules\%2Frequest.php\%3Fmodule\%3Doc_ program\%26action\%3Dview.php\%26a\%3D\%26id\%3D24\%26type\%3D4\&clen=315010. 13. prosinca 2021.

2. Barbieri, Alberto. 2020. Digitalna kompetencija nastavnika u kontekstu stručnog usavršavanja. Diplomski rad. Sveučilište Jurja Dobrile u Puli. https://repozitorij.unipu.hr/ islandora/object/unipu\%3A4740/datastream/PDF/view. 16. listopada 2021.

3. Carnet. Nastava na daljinu. https://www.carnet.hr/usluga/udaljenoucenje/. 14. prosinca 2021.

4. Europska komisija. 2021. Akcijski plan za digitalno obrazovanje (2021. - 2027.). https:// ec.europa.eu/education/education-in-the-eu/digital-education-action-plan_hr). 5. studenog 2021.

5. Jelavić, F. 2003. Nastavna metoda u odgojno-obrazovnom procesu. Kateheza: časopis za vjeronauk u školi, katehezu i pastoral mladih, 25 (4): 277-287.

6. Kučina Softić, Sandra. E-učenje i nastava online na Sveučilištu u Zagrebu. http://www. unizg.hr/fileadmin/rektorat/Studiji_studiranje/Studiji/Kvaliteta/4._Sveucilisni_dan_ kvalitete/SKS-tekst.pdf. 20. listopada 2021.

7. Ministarstvo znanosti, obrazovanja i sporta. 2015. Nove boje znanja: strategija obrazovanja, znanosti i tehnologije. https://mzo.gov.hr/UserDocsImages/dokumenti/Obrazovanje/Strategija\%20obrazovanja,\%20znanosti\%20i\%20tehnologije.pdf. 16. listopada 2021.

8. Perkov, D. 2019. Upravljanje promjenama u poslovnoj organizaciji digitalnog doba. Narodne novine.

9. School Education Gateway. 2020. Digitalna kompetencija: ključna vještina nastavnika učenika u 21. stoljeću. https://www.schooleducationgateway.eu/hr/pub/resources/tutorials/digital-competence-the-vital-.htm. 12. listopada 2021.

10. Siemens, G. 2004. Connectivism: A learning theory for the digital age.

11. Zoretić, D., Čizmek Vujnović, O. i Ilić, M. 2021. Primjena nastavničkih funkcija i kompetencija u uvjetima nastave na daljinu, u: Računovodstvo i menadžment - RiM: 22. međunarodna znanstvena i stručna konferencija. Zbornik radova s međunarodne znanstvene i stručne multipoint video konferencije. Svezak II. - stručni radovi. Zagreb: 87-100. 


\title{
Libertas International University students' satisfaction with classes during covid-19 pandemic \\ Abstract
}

\begin{abstract}
Since the beginning of 2020, Croatia has faced the Covid-19 pandemic. With the spread of the pandemic, many schools and colleges were closed, and transitioned to online classes. Fortunately, many schools and colleges had previously developed platforms for the organization of distance learning. Faced with an escalating epidemiological situation, Libertas International University suspended direct contact classes at the end of March 2020. In the beginning, both the students and the teachers were ill-prepared for the new form of teaching/ learning, and it took some time to adapt. Although the students and the teaching staff had acquired and applied digital competencies and skills in their everyday life and work, many found themselves unprepared for online teaching, or following online lectures and seminars. In short, it is necessary that all students and teachers acquire similar levels of digital competence. A survey was conducted with students of the specialist graduate study at the Libertas International University, with questions relating to students' digital competence, distance learning, student assessment. The results are presented in this paper.
\end{abstract}

Key words: online classes, digital competencies, students, pandemic 